\title{
Green Development Path in Exhibition Construction: Empirical Research
}

\author{
Xueming Liu \\ Department of MICE, School of Economics and \\ Commerce \\ South China Uni. of Technology \\ Guangzhou, 51006,China \\ 110012485@qq.com
}

\author{
Xianhui Feng \\ Department of MICE, School of Economics and \\ Commerce \\ South China Uni. of Technology \\ Guangzhou, 51006,China \\ xhfeng@scut.edu.cn
}

\begin{abstract}
Exhibition can gather a large scale of exhibits, exhibitors and visitors in a short time, and make them exchange information, conclude the transaction. It has wonderful publicity effect and it is strong in their industries promotion. When exhibition construction industry vigorous development and bring economic and social benefits, the pattern of disposable types of build and consume a large amount of building materials of exhibition construction, produced a huge amount of resources waste and environmental pollution. Toachieve Sustainable Development of Exhibition industry, its building technology must go green development path, low carbon development, reduce the use of resources, based on principles of resources reuse, recycling, improve the efficiency of the use of resources and energy, reduce waste emissions, to achieve the maximization of economic, social and ecological benefits. Based on actual sample exhibition construction, there are analyses of different ways of consumption of materials with types of structures, and calculate the "reduction" and "recycling" resource savings in the building implementation. The results shows that "reduction" and "recycling" is a green development path of exhibition engineering industry to achieve minimum material consumption and the resource can be recycled many times.
\end{abstract}

Keywords-exhibition industry; engineering technology; recycling; reduction

\section{INTRODUCTION}

Exhibitionconstruction grows rapidly nowadays in China. Up to the year 2011, with total exhibition area over 4million square meters, China became a country which had the second largest exhibition area in the world right after German [1]. With the development of Chinese exhibition industry, significant negative impacts, especially the solid material waste and environmental pollution, should be realized. According to a research report, Canton Fair generates more than 40 thousand tons solid waste after the exhibition and it's been said that around $70 \%$ to $80 \%$ solid waste generates in booth building and removing period[2]. Therefore, it's absolutely necessary to change the traditional one-way economic pattern like resourceproduce-waste into a green development path.

\section{RESEARCH MODEL AND SAMPLES}

Five booths have been selected as research samples in this paper. We make a list of building material of these samples, and try to figure out resources consumption according to empirical data. Further, that have been forecasted how much materials can be saved through reduction and recycling processes.

There are many kinds of materials in booth building, such as wood, metal, plastics, glass, plasterboard and so on. All of them can be divided into two main types, standard booth materials and special tailor-made. Standard booth materials as same as building blocks, which convenient to install and transport but poor at flexibility and applicability and can be used many times, but the special tailor-made ones are the opposite which can be used only once and flexibility. Although a large amount of enterprises devote to developing new materials, special tailor-made wood and steel structure or wood structure still perform better in presenting the booth design elements, and that's why the exhibition building creates a huge demand of wood. Being an indispensable part of an exhibition, each individual booth can be treated as a micro-system in the exhibition industry chain. At last, five booths with different features are chosen as research samples.

\section{RESEARCH METHOD}

For simplified calculation about five samples, the materials are concluded in three varieties, wood, plastic and others. And with an aim to compare the material consumption, the booth area of each sample is assumed to $9 \mathrm{~m} 2$ (Area of a standard booth) [3]. The material consumption were been calculated as shown below. It's been proved that material consumption is mainly influenced by two factors, one is the booth structures, and the other is the ratio between standard materials and special materials. 
TABLE I. THE MATERIAL CONSUMPTION OF THE SAMPLES

\begin{tabular}{|c|c|c|c|c|c|c|}
\hline \multirow[b]{2}{*}{ No. } & \multirow[b]{2}{*}{$\begin{array}{c}\text { Area } \\
\left(\mathrm{m}^{2}\right. \\
)\end{array}$} & \multirow{2}{*}{$\begin{array}{c}\text { Standard } \\
\text { Materials : } \\
\text { Special } \\
\text { Materials } \\
(\%: \%)\end{array}$} & \multirow[b]{2}{*}{$\begin{array}{c}\text { Booth } \\
\text { structure }\end{array}$} & \multicolumn{3}{|c|}{ Material } \\
\hline & & & & $\begin{array}{c}\text { Wood } \\
\left(\mathbf{m}^{3}\right)\end{array}$ & $\begin{array}{c}\text { Plastics } \\
\left(\mathbf{m}^{2}\right)\end{array}$ & $\begin{array}{c}\text { Others } \\
\left(\mathbf{m}^{2}\right)\end{array}$ \\
\hline Sample1 & 9.00 & $0 \%: 100 \%$ & $\begin{array}{l}\text { Special booth } \\
\text { with wood } \\
\text { structure }\end{array}$ & 4.27 & 2.88 & 0.73 \\
\hline Sample2 & 9.00 & $25 \%: 75 \%$ & $\begin{array}{l}\text { Special booth } \\
\text { with steel and } \\
\text { wood structure }\end{array}$ & 2.83 & 5.28 & 2.71 \\
\hline Sample3 & 9.00 & $50 \%: 50 \%$ & $\begin{array}{l}\text { Special booth } \\
\text { with steel and } \\
\text { wood structure }\end{array}$ & 2.19 & 8.20 & 0.81 \\
\hline Sample4 & 9.00 & $75 \%: 25 \%$ & $\begin{array}{l}\text { Special booth } \\
\text { with aluminum } \\
\text { alloy structure }\end{array}$ & 0.31 & 8.45 & 0.00 \\
\hline Sample5 & 9.00 & $100 \%: 0 \% \ldots$ & Standard booth & 0.00 & 0.00 & 5.76 \\
\hline
\end{tabular}

Aluminum alloy structures, steel and wood structures and wood structures are widely used in exhibition booth design. Sample1 is wood structure, sample 2 and 3 are steel and wood structure, sample 4 is aluminum alloy structure and sample5 is a standard booth. From table1, it can be found that sample1 used the most wooden materials while sample5 used the least, and an average of wood consumption among the samples is 1.92 . Besides, sample2, sample 3 and sample 4 cause the most plastic consumption than sample1 and sample5, it indicates that standard booths need less plastic materials than special ones. What's more, the plastics material consumption rate is increasing from sample1 to 4 when the wooden material consumption rate is decreasing, that means metal structures use more plastic but less wood than wooden ones.

Whether the total material consumption is relative to the ratio of standard materials or not, all the statistics are standardized. Shown as fig.1, with the ratio of standard materials increasing, total material consumption is getting lower and lower. It's obvious that there's a negative correlation between total material consumption and the ratio of standard material. Sample5 is an idealized model for reducing, because all the building materials can be reused after the exhibition. But in fact, this situation is hardly seen in China by the reason of technical limitation.

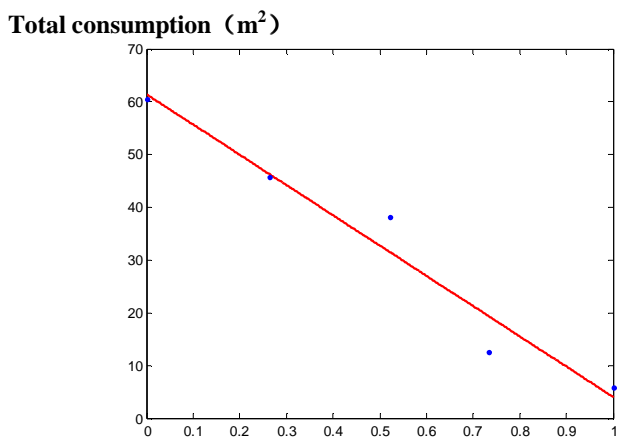

Ratio of standard materials

FIGURE I. LINEAR FITTING CHART OF THE RELATIONSHIP BETWEEN THE RATIO OF STANDARD MATERIALS AND TOTAL CONSUMPTION
To compare the efficiencies of reduction and recycling, materials are assumed to be recycled for three times, and the initial state of sample4 is regarded as the reduction result of sample1. According to table1, it's an efficient way to save building materials by taking both reduction and recycling measures and either of them. Moreover, for sample1, the material consumption after reduction is $12.58 \mathrm{~m} 2$ while its $19.93 \mathrm{~m} 2$ after recycling; it indicates reduction is more effective than recycling.

TABLE II. COMPARISON BETWEEN THE EFFICIENCIES OF REDUCTION AND RECYCLING

\begin{tabular}{c|c|c|c|c|c|c}
\hline No. & Sample & $\begin{array}{c}\text { Initial } \\
\text { material } \\
\text { consumption } \\
\left(\mathbf{m}^{2}\right)\end{array}$ & $\begin{array}{c}\text { Current } \\
\text { material } \\
\text { consumption } \\
\left(\mathbf{m}^{2}\right)\end{array}$ & $\begin{array}{c}\text { Initial : } \\
\text { Current } \\
(\%)\end{array}$ & $\begin{array}{c}\text { Material } \\
\mathbf{s a v i n g} \\
\left(\mathbf{m}^{2}\right)\end{array}$ & $\begin{array}{c}\text { Material } \\
\text { saving } \\
(\%)\end{array}$ \\
\hline 1 & Sample1 & 60.54 & 60.54 & 0 & 0 & 0 \\
\hline 3 & $\begin{array}{c}\text { Rample1 } \\
\text { (as } \\
\text { sample 4) }\end{array}$ & 60.54 & 12.58 & $20.78 \%$ & 47.96 & $79.22 \%$ \\
\hline $\begin{array}{c}\text { Recycled } \\
\text { sample1 }\end{array}$ & 60.54 & 29.93 & $49.44 \%$ & 30.61 & $50.56 \%$ \\
\hline $\begin{array}{c}\text { Reduced } \\
\text { and } \\
\text { recycled } \\
\text { sample1 } \\
(\text { as } \\
\text { recycled } \\
\text { sample4) }\end{array}$ & 60.54 & 6.30 & $10.41 \%$ & 54.24 & $89.59 \%$ \\
\hline
\end{tabular}

\section{DISCUSS: MEASURES FOR GREEN DEVELOPMENT OF EXHIBITION CONSTRUCTION BASED ON MATERIAL REDUCTION AND RECYCLING}

First of all, Suppliers should continually take their responsibilities to improve the techniques as well as develop new eco-materials for a purpose to satisfy various exhibitors' demands. Next, it's common that special materials which can't be recycled are still used broadly in the exhibition industry although exhibitors begin to realize the importance of environment protection. Actually, designers consider much more about the booth design element and decoration but less on energy saving and emission reduction. Further, most of the exhibitors have a long-term partnership with a fixed contractor, and that explains why it's difficult for eco-materials to establish a market. Hence, it's essential for exhibitors to take the lead to use recycled eco-materials and create an environmental friendly atmosphere. Third-party supervision also plays an irreplaceable role in reducing building materials. Reduction measures will be more feasible if there're any access restrictions of exhibition. It suggests that unless a contractor is qualified and the booth design meets the standards of material consumption, it will be rejected by the exhibition venue. In this point of view, exhibition venues and organizers are supposed to restrict and encourage the contractors to recycle the building materials, and if the contractors reach the goal, they will be rewarded with a particular benefit. 
At present, because there is a lack of specialist exhibition building materials recycling enterprises in the market, most of the materials cannot be recycled after the show. Therefore, industry associations or exhibition organizers should cooperate with the existing recycling enterprises, so that all the materials can be recycled and classified by the recycling enterprises.

\section{CONCLUSION}

The quantitative method is used to compare the material consumption in five different samples. It shows that reduction and recycling play an important part in saving booth building material and the sustainable development in exhibition industry. And it's been proved that reduction play more important role in decreasing material consumption than recycling. Besides, increasing the usage rate of standard material do help to reduce resources consumption, so exhibition enterprises ought to take their efforts to develop and promote new material while the supervision should take measures to avoid the negative effects of market economy. To sum up, based on the idea of building material saving and environmental friendly, a green development system of exhibition construction through material reducing and recycling will become a trend in exhibition industry.

\section{ACKNOWLEDGMENT}

The study was supported by the Science and Technology Service Foundation of G.D province (to FENG Xianhui)(No.2012B040303006); The Fundamental Research Funds for the Central Universities (to FENG Xian-hui)(No. 2014X2D 07); The Youth Fundamental Research of School of Economic and Commerce, SCUT.

\section{REFERENCES}

[1] Jurong GUO, etc. The Report of Chinese MICE Eco-development [M].Beijing: Social sciences academic press.2012:2-11.

[2] Ailing ZHAO. "Green EX.: The Trend of Exhibition Industrial [J]. China's foreign trade.2010.2:58-61.

[3] Xianhui FENG, Shaozen WANG. Exhibition design [M].People University Press. 2011:70-78. 